\title{
Lukasz Arendt
}

\section{LABOUR MARKET AS DETERMINANT OF FUNCTIONING OF LOCAL PRODUCTION SYSTEMS - THE CASE OF LODZKIE REGION AND NOVOSIBIRSK OBLAST}

\begin{abstract}
The development of local production systems depends on many interlinked factors - localisation, available infrastructure, the abundance of natural resources, stock of human capital, etc. Undoubtedly, human resources play a crucial role in the creation and development of LPS, especially in cases, where competitive advantage of a LPS is knowledge-intensive based. The paper presents the changes on the labour market in two regions: Lodzkie Region and Novosibirsk Oblast in order to discuss the way, in which human capital and labour market situation may determine the development of local production systems in these regions. Research results show, that it is fundamental both to invest in human capital and to develop educational and research potential in accordance with labour market needs in order to reduce detrimental impact of society ageing in these regions.
\end{abstract}

Key words: labour market, employment, local production systems, regional policy.

\section{INTRODUCTION}

Local production systems (LPS) are complex entities within which social, economic, institutional and geographical factors are closely entwined (Lombardi 2003). There are many methodological proposals and approaches (theoretical as well as empirical) within which LPS may be analysed ${ }^{1}$. One of the most popular approach is consistent with the Porter's terminology, in which LPS is seen as a cluster created by many specialized companies, where important features of the cluster system are connected with the experience of these companies and social relations in local communities. Regardless of the approach, it is emphasised that the creation and evolution of local production systems lead to changes in the division and distribution of labour, which are related to the changes in the techno-organisational configuration taking place in companies within LPS. However, it should also be noted that further development of LPS is linked to the situation on the regional and local labour markets, especially the potential of human resources available on these markets.

* University of Lodz, Faculty of Economics and Sociology, Department of Economic Policy.

${ }^{1}$ For a comprehensive discussion on different methodological approaches see e.g. (Suzigan et al. 2007). 
Undoubtedly, human resources (human capital) ${ }^{2}$ play a crucial role in the creation and development of LPS, especially in these cases, where competitive advantage of LPS is knowledge-intensive based. In other words, LPS influence the labour market, while at the same time labour market influences LPS. The aim of the paper is to focus on the latter relation and to present the changes on the labour market in two regions: Lodzkie Region and Novosibirsk Oblast. The paper analyses the way, in which human capital and labour market situation may determine the development of local production systems in these regions ${ }^{3}$ - it refers to a broader discussion on factors influencing the creation and development of LPS.

\section{DEVELOPMENT POTENTIAL OF LODZKIE AND NOVOSIBIRSK REGIONS}

Novosibirsk Oblast is considered by the Interregional Association of Russian Innovative Regions as one of top innovative leaders (Untura 2013). In one of the long-term scenarios of socioeconomic development for Russian Federation (the scenario assumes that Russian government stimulates economic growth, which results in the increase in accumulation to at least $25-30 \%$ of the Gross National Product, as well as introduces innovation and modernisation measures), yearly GNP growth is expected to reach $5-7 \%$ by the mid 2020 's, and the share of Siberia in the national economy is planned to rise to around $25 \%$. In this scenario Novosibirsk will become one of the innovation generating and adopting centres (Granberg et al. 2011) $)^{4}$.

Development potential of the Novosibirsk Oblast is also confirmed by economic forecasts based on the SIRENA-2M model (it is a modified version of SIRENA-2 model developed at the Institute of Economics and Industrial Engineering, Siberian Branch of the Russian Academy of Sciences). The analysis for the Siberian Federal District conducted at macroregional level pointed out that

${ }^{2}$ Although in this paper the terms "human resources" and "human capital" will be treated as synonyms, it should be emphasised, that the latter is perceived in the literature as a more complex, dynamic and quality-oriented phenomenon in comparison to the notion of human resources (for a comprehensive review see Samul 2013).

${ }^{3}$ To ensure comparability of data for Lodzkie Region and Novosibirsk Oblast, analysis is based on the data downloaded from OECD database. The choice of the regions for the analysis reflects the scope of primary research conducted with the financial support of the project under the International Research Staff Exchange Scheme (IRSES) - Marie Curie Actions No. FP7-PEOPLE-2011 IRSES 295050 Functioning of the local production systems in the Conditions of Economic Crisis (Comparative Analysis and Benchmarking for the EU and Beyond) (acronym FOLPSEC). The FOLPSEC project financed Author's one-month research study at the Institute of Economics and Industrial Engineering of Siberian Branch of the Russian Academy of Sciences in Novosibirsk.

${ }^{4}$ For analysis of innovation dynamics, R\&D expenditures and GRP patterns see (Romanova et al. 2012). 
the South3N1 region (the Republic of Altai, Altai krai, Omsk and Novosibirsk Oblasts) reflects greater readiness to transit to innovative development, and thus it develops faster than other macroregions. Moreover, South3N1 region, including the Novosibirsk Oblast, is expected to play a special role in the development of the Siberian Federal District (Suspitsyn 2012).

According to the typology presented in Vavilina (2013), the Novosibirsk Oblast is classified as a region that is effective (in terms of available social infrastructure), innovative (in terms of social capital), affiliate (when it comes to social relations), productive (when it comes to the development of civil society institutions ${ }^{5}$ ), and democratic (in terms of the development of interregional cooperation).

The analysis of cluster models in the Rus sian Federation demonstrates that in Siberia the approach to cluster initiatives is based on the innovative model focused on biotechnology, science of live micro- and macroorganisms, medicine, and nanotechnology. The model is aimed at rising the competitiveness of industry and the region in order to provide qualitative and quantitative results. Of course, different regions within the Siberian Federal District have different specialisations, which include Information and Communications Technologies, microelectronics, and biotechnology as potential orientation of industrial clusters in the Novosibirsk Oblast (Lenchuk, Vlaskin 2010).

More and more attention in Russian Federation has been put on the issues of regional strategic planning, which is reflected in the growing number of medium and long-term programmes and documents. In the Novosibirsk Oblast the core of the system of strategic planning is based on many documents: the strategy of region's socio-economic development till 2025, territorial development plan till 2025, programme of socioeconomic development until 2015, "Strategic Plan for the Sustainable Development of the City of Novosibirsk", "Master Plan of Novosibirsk" and a system of long and medium-term programmes of administrative districts and municipalities. It is worth to mention, that Novosibirsk Oblast is the only region in the Russian Federation, in which strategic documents were developed by specialists ${ }^{6}$. The strategy for the Novosibirsk Oblast has got a solid analytical base - it takes into account demographic changes (two options are considered: increase or decrease of population), employment forecast ${ }^{7}$, and presents resources (e.g. investments, labour) needed to implement the strategy (Seliverstov, Melnikova 2013).

${ }^{5}$ It is emphasised that institutional structure of civic society has been developing most rapidly in the Novosibirsk Oblast (within the regions of the Siberian Federal District) - one of the measures confirming this phenomenon is the high number of Non-Governmental Organisations operating in the Novosibirsk Oblast in comparison with other Siberian regions.

${ }^{6}$ The strategy for the Novosibirsk Oblast was developed by the Institute of Economics and Industrial Engineering, Siberian Branch of the Russian Academy of Sciences.

${ }^{7}$ The strategy for the Novosibirsk Oblast foresees employment increase in the future (Seliverstov, Melnikova 2013). 
Labour market situation, especially the abundance of human resources, is seen as an important factor determining the development prospects of different regions within the Siberian Federal District. Analysis of regional strategic documents revealed the existence of interregional competition for the labour force - basically all regions are focused on attracting human resources by positioning themselves as "the most attractive places to live in Siberia" (Seliverstov, Melnikova 2013).

Novosibirsk Oblast seems to be well prepared for development challenges, as far as institutional framework for supplying regional economy with human capital is concerned. The education system in the Novosibirsk Oblast is well developed, the region is a part of the West Siberian educational cluster focused on socio-cultural and research specialization (Vavilina 2013). PricewaterhouseCoopers pointed at unique human resources, academic potential and capacity for innovation as one of the competitive advantages of the Novosibirsk Oblast (PWC 2011: 28). Akademgorodok founded in the 1950s, which is considered to be the first "cluster initiative" on a larger scale initiated in the Novosibirsk Oblast, plays an important role in education. Because of its presence, Novosibirsk Oblast has one of the highest numbers of researchers in the Russian Federation (Perret 2014: 175). While it is argued that Russian science is unable to provide research support to technology parks and the transfer of knowledge from science centres to innovative enterprises is still an unresolved issue, the Novosibirsk Oblast is an example of strong cooperation between science and business (Petukhova 2011).

The Lodzkie Region, like the Novosibirsk Oblast, is also seen as a region with high development potential. Excellent location (the Lodzkie Region is located in the central part of Poland, at the intersection of several major arterial roads: Berlin-Moscow and Gdańsk-Vienna) combined with solid research base (there are three main public universities in the region - the University of Lodz, the Lodz University of Technology and the Medical University in Lodz, which participate in EU Framework Programme projects and maintain research cooperation with foreign universities; there are also many private colleges in the region) and focus on the concept of Open Innovation create competitive environment for local production systems (OECD 2013b; EURIS 2013).

However, the innovation potential of the Lodzkie Region has been not fully utilized - in accordance with the Regional Innovation Scoreboard 2012, Lodzkie Region was a poor innovator with progressive dynamics of innovation growth (LORIS 2030, 2013). It is emphasised, that one of the main challenges for the region is to change this situation and try to eliminate the gap between the Lodzkie Region and some West European regions by 2030 (EURIS 2013) ${ }^{8}$.

${ }^{8}$ Although the development gap between the Lodzkie Region and highly-developed regions of the Western Europe is perceptible, it should be emphasised, that socio-economic performance of the 
The other important challenge is counteracting the effects of the ageing society and negative migration balance. Migration from Lodzkie Region (especially from the capital city - Lodz) is caused mainly by economic pull-factors of the neighbour region of Mazowieckie. Many inhabitants move from the Lodzkie Region to Warsaw for education and employment opportunities. Forecasted decline in population in the Lodzkie Region, according to the Polish Central Statistical Office, will continue until 2035, resulting in a loss of young and skilled professionals in the region, unless strategic decisions are made to rectify the situation (OECD 2013b).

Strategic planning in the Lodzkie Region is based on two main regional strategies: Regional Development Strategy for the Lodzkie Region 2020 and Regional Innovation Strategy LORIS 2030, which were adopted by the Regional Parliament in the first half of 2013. Regional Development Strategy presents the vision, in which Lodzkie Region is cohesive both territorially and in terms of its image, creative and competitive at national and European levels, accessible by different means of transport, distinguished by its attractiveness to investors and high quality of life. The mission for the Lodzkie Region is to deliver an integrated and territorially oriented policy of sustainable development, based on economic cooperation, social relations and regional identity (Lodzkie 2020, 2013: 73). The main pillar of development, pointed out in the Strategy, is an advanced economy based on knowledge and innovation. To create such an economy, technological restructuring should take place by 2020. The Strategy emphasises the need for (Lodzkie 2020, 2013; EURIS 2013):

- the implementation of modern technologies in the key industries of the region,

- the introduction of intelligent economic specialisations, that will enable the building of permanent competitive advantages,

- the development of cooperation networks and a research sector responding more accurately to the needs of the economy.

These actions, linked to goals and proposals listed in the RIS LORIS 2030, should create increasingly better conditions for the development of local production systems in the Lodzkie Region. The analysis prepared in the framework of RIS LORIS 2030 distinguished six regional smart specialisations: modern textile and fashion industry (including design); advanced building materials; medicine, pharmacy, cosmetics; energy, including generation of energy from renewable energy sources; innovative agriculture and food processing; IT and telecommunications.

Lodzkie Region is much better than in the Novosibirsk Oblast - comparable OECD data show that GDP per capita in 2011 (measured in US dollars, PPP constant prices for 2005) was two times higher in the Lodzkie Region (16 615 USD compared to 8164 USD); Gross Value Added per worker in 2005 was $62 \%$ higher (in the OECD database for the period 2000-2012 the only GVA data available for the Novosibirsk Oblast is for the year 2005). Life expectancy in the Lodzkie Region in 2009 was 74.1, while in the Novosibirsk Oblast 68.9 (The Territories of the Russian Federation 2012). 
At the same time, four key technological areas that should support economic development of the region were chosen: biotechnology; nanotechnologies and functional materials; mechatronics; and Information and Communication Technologies (LORIS 2030, 2013).

These specialisations and technological areas seem to be linked with the current state of the art as for development of LPS in the Lodzkie Region. The initiatives launched within the framework of local production systems in the region include cluster cooperation, special economic zones, technology parks, and technology transfer centres.

The analysis conducted in 2009 revealed the existence of 17 cluster initiatives in the Lodzkie Region. Most of the clusters operated in technological areas listed in the RIS LORIS 2030 (e.g. Cluster BioTechMed, Nanotechnology Cluster, ICT Central Poland Cluster) (see PAG Uniconsult 2009).

The Lodz Special Economic Zone is one of important stakeholders that support regional development potential and contribute to enhanced capacity of the LPS. It is one of the best performing special economic zones in Poland (KPMG 2012). Since 1997 it has issued around 240 permits to pursue an economic activity in the Zone. Companies that invested in the Lodz Special Economic Zone operate in the following industries: cosmetics and pharmaceuticals, household appliances, BPO, IT, medical equipment, building materials, food processing, packaging, plastics, R\&D and logistics.

The other important stakeholder, from the innovation policy point of view is the Lodz Regional Science and Technology Park (Technopark Lodz). Its unique feature is the establishment of BioNanoPark based on modern bio- and nanotechnology laboratories and offering research services mainly to SMEs. Individual Medical Implant Laboratory operating in the Technopark is the only one in Poland to construct models that allow to precisely adjust implants in damaged bones (PARP 2011: 24).

High importance of cooperation between science and business has been noticed by the universities in the Lodzkie Region. Lodz University of Technology and the University of Lodz created technology transfer centres in order to facilitate this cooperation.

\section{DEMOGRAPHIC PERSPECTIVE}

Population of the Lodzkie Region in 2012 accounted for $6.6 \%$ of the population of Poland, a significantly higher share than in the case of the Novosibirsk Oblast (1.9\% of Russian Federation's population). However, data reveal a downward spiral of this share for the Lodzkie Region, which is losing its relative position in Poland, while the Novosibirsk Oblast recorded a slight increase between 2000 and 2012. 
In both regions we witnessed population decline, however the decrease, in relative terms, was almost 3 times higher in Lodzkie Region in comparison to the Novosibirsk Oblast. As a result, the difference in population between Novosibirsk and Lodzkie has soared from 77,061 persons in 2004 to 153,182 persons in 2012 (Table 1).

Table 1

Population in the Lodzkie Region and the Novosibirsk Oblast

\begin{tabular}{|c|c|c|c|c|c|}
\hline \multirow{3}{*}{ Year } & \multicolumn{4}{|c|}{ Region } & \multirow{3}{*}{$\begin{array}{l}\text { Difference } \\
\text { Novosi- } \\
\text { birsk-Lodz- } \\
\text { kie }\end{array}$} \\
\hline & \multicolumn{2}{|c|}{ Lodzkie } & \multicolumn{2}{|c|}{ Novosibirsk } & \\
\hline & persons & $\begin{array}{l}\% \text { of country } \\
\text { population }\end{array}$ & persons & $\begin{array}{c}\% \text { of country } \\
\text { population }\end{array}$ & \\
\hline 2000 & 2637438 & 6.9 & 2725499 & 1.8 & 88061 \\
\hline 2001 & 2627824 & 6.9 & 2715128 & 1.8 & 87304 \\
\hline 2002 & 2617318 & 6.8 & 2703012 & 1.8 & 85694 \\
\hline 2003 & 2607380 & 6.8 & 2688423 & 1.8 & 81043 \\
\hline 2004 & 2597094 & 6.8 & 2674155 & 1.8 & 77061 \\
\hline 2005 & 2587702 & 6.8 & 2665984 & 1.8 & 78282 \\
\hline 2006 & 2577465 & 6.8 & 2654853 & 1.8 & 77388 \\
\hline 2007 & 2566198 & 6.7 & 2647195 & 1.8 & 80997 \\
\hline 2008 & 2555898 & 6.7 & 2642727 & 1.8 & 86829 \\
\hline 2009 & 2548861 & 6.7 & 2648923 & 1.8 & 100062 \\
\hline 2010 & 2541832 & 6.7 & 2661594 & 1.8 & 119762 \\
\hline 2011 & 2542436 & 6.6 & 2666465 & 1.8 & 124029 \\
\hline 2012 & 2533681 & 6.6 & 2686863 & 1.9 & 153182 \\
\hline
\end{tabular}

Source: OECD database.

Another significant difference between the regions that determines spatial availability of human resources, which, in turn, influences the possibility of LPS development, is population density. In the Lodzkie Region population density fell from 145 persons $/ \mathrm{km}^{2}$ in 2000 to 139 persons $/ \mathrm{km}^{2}$ in 2012, but was still much higher than in Novosibirsk Oblast $\left(15\right.$ persons $\left./ \mathrm{km}^{2}\right)$. Population in the Novosibirsk Oblast is concentrated in the capital of the region - the city of Novosibirsk ${ }^{9}$ (in $201256 \%$ of the population lived in city of Novosibirsk). In Lodzkie Region the role of the capital city - Lodz - is much smaller (in 2012

${ }^{9}$ Novosibirsk is the third biggest city in the Russian Federation (after Moscow and St. Petersburg) and one of the two megapolises (next to Omsk) in the Siberian Federal District, situated farthest to the east in the Russian Federation (Perret 2014: 30). 
Lodz accommodated "only" $28 \%$ of the population of the region). These features clearly show that LPS are and will be much more concentrated in the Novosibirsk Oblast than in the Lodzkie Region.

The comparison of the population structure between Lodzkie Region and Novosibirsk Oblast in the three economic groups (pre-working, working and post-working age population ${ }^{10}$ ) shows, that although both regions are facing structural problems, the Novosibirsk Oblast is in a relatively better situation.

Both regions witnessed a sharp decline in the pre-working age population - the number of people in the 0-14 age group fell in Novosibirsk Oblast by $16.9 \%$ between 2000 and 2012, and in Lodzkie Region by 24.5\%! Moreover, while in Lodzkie Region this decline was continuous, in the Novosibirsk Oblast the trend was reversed in 2009 and since then, pre-working age population has started growing by average $2 \%$ annually (see Figure 1 ).

Changes in the working-age population followed different development paths in these two regions. In Lodzkie Region, slow growth of the working-age population till $2006(0.1-0.3 \%$ annually) was replaced in $2007-2010$ by a slight decrease (up to $-0.1 \%$ annually) and then in 2012 by a sharp fall that accounted for $1.0 \%$ (as a result the working-age population fell by $0.3 \%$ between 2000 and 2012). In the Novosibirsk Oblast changes in the working-age population followed sinusoidal trajectory (number of people aged 15-64 grew by $2.0 \%$ between 2000 and 2012). However, the most important fact is the existence (from 2007) of the significant growth trend (see Figure 2).

The post-working age population grew in both regions between 2000 and 2012 (by $4.6 \%$ in Lodzkie Region, and by 1.2\% in the Novosibirsk Oblast). The growth trajectories were similar, but the pace of changes was noticeably different. In both regions the post-working age population grew between 2000 and 2007, however in Lodzkie Region the annual rate of growth fluctuated between $0.1 \%$ and $0.7 \%$, while in the Novosibirsk Oblast it was higher and reached $2.8 \%$ in 2003 . In the 2008-2011 period in the Lodzkie Region the post-working age population decreased insignificantly (the rate of change varied between $-0.1 \%$ and $-0.4 \%$ annually), while in the Novosibirsk Oblast the fall was evident, reaching even $3.3 \%$ annually in 2009. In 2012 the trend was reversed, in Novosibirsk Oblast the post-working age population increased by $0.8 \%$, while in Lodzkie Region it grew by $3.4 \%$ (see Figure 3 ).

It is evident that, from the perspective of the future potential of human capital, the aforementioned shifts (in absolute terms) in the three population groups were more unfavourable in the Lodzkie Region. These shifts resulted in structural change in the population.

${ }^{10}$ In the paper, pre-working age population is defined as age group $0-14$ years old, working age group: $15-64$, and post-working age group: $65+$. 


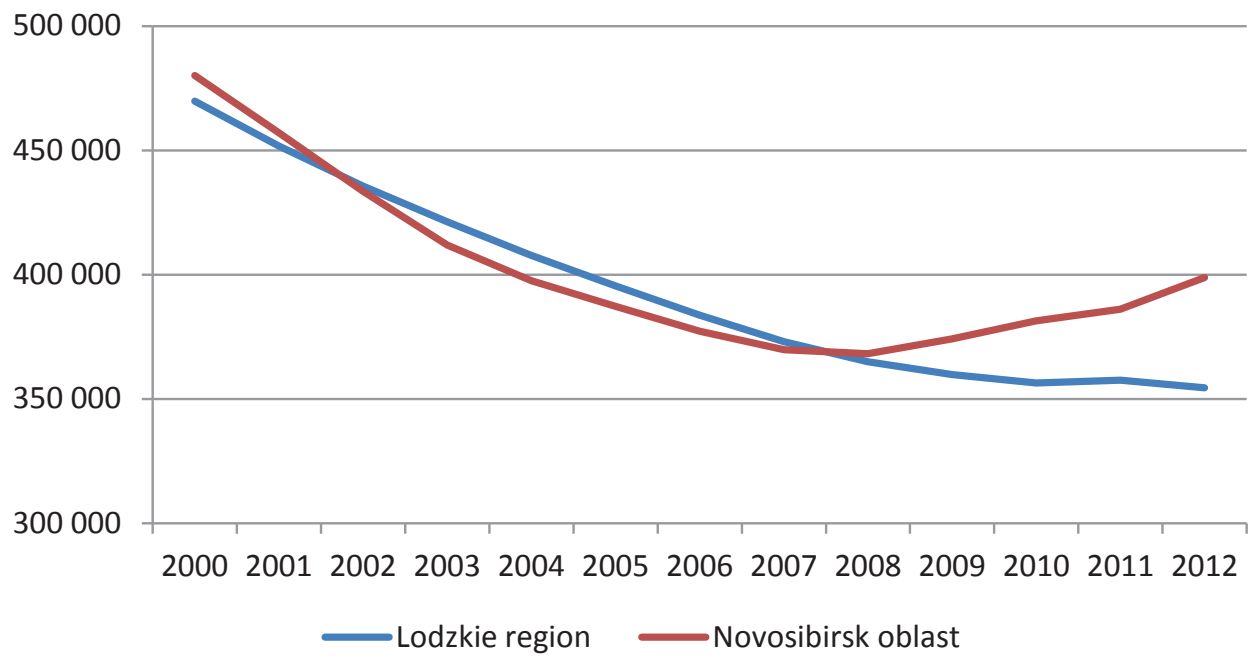

Figure 1. Population 0-14

Source: OECD database.

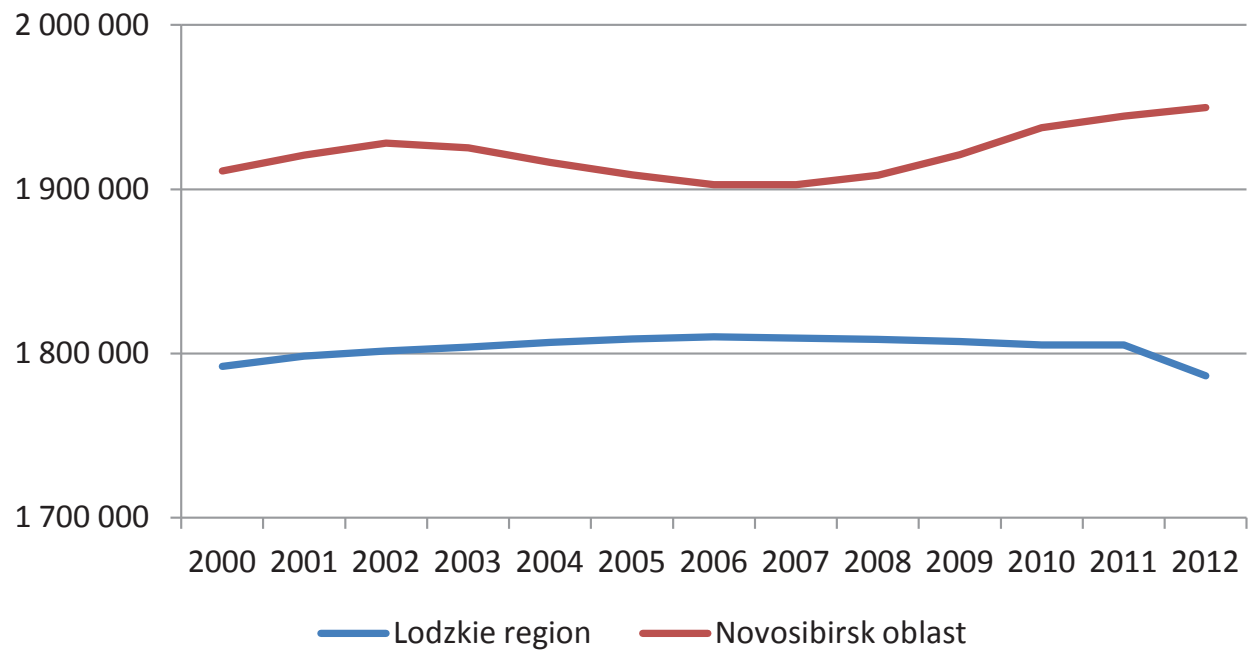

Figure 2. Population 15-64

Source: OECD database. 


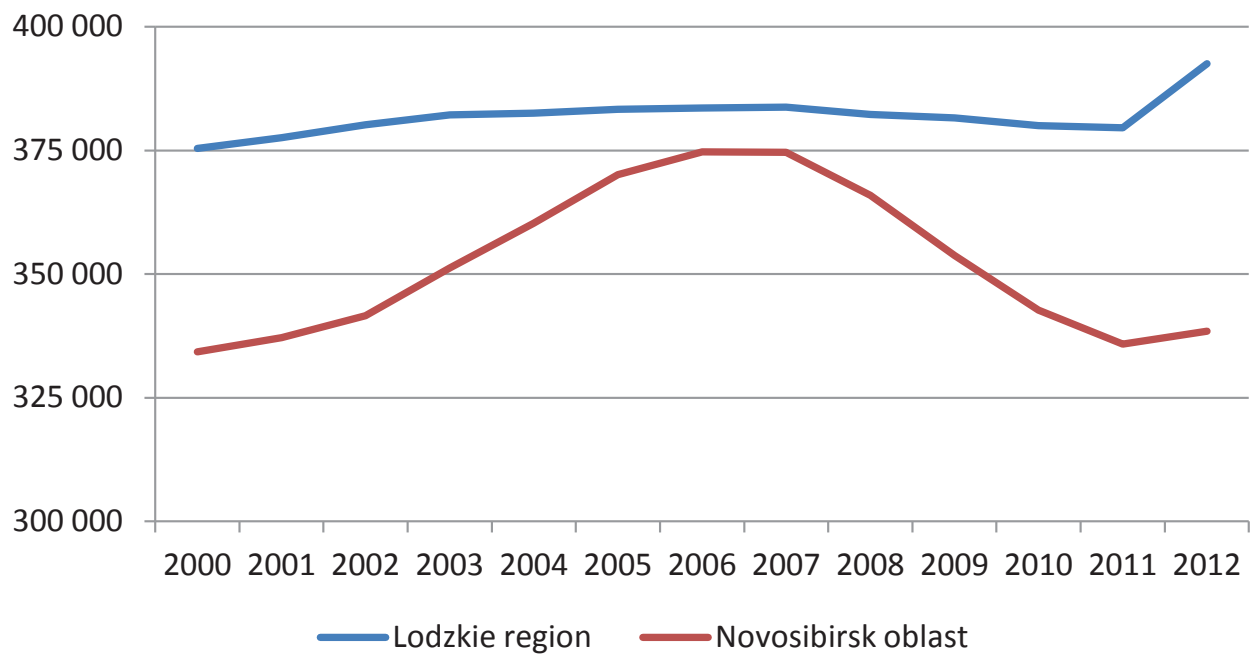

Figure 3. Population 65+

Source: OECD database.

Although in both regions the share of the working-age population increased between 2000 and 2012 by 2.5 percentage points (from $68.0 \%$ to $70.5 \%$ in the Lodzkie Region, and from $70.1 \%$ to $72.6 \%$ in the Novosibirsk Oblast), a slightly growing share of the post-working age population and, particularly, a relatively high decrease in the share of pre-working population may be distressing (see Table 2).

Table 2

Structure of the population in the Lodzkie Region and Novosibirsk Oblast

\begin{tabular}{|c|c|c|c|c|c|c|}
\hline Region & \multicolumn{3}{|c|}{ Lodzkie } & \multicolumn{3}{c|}{ Novosibirsk } \\
\hline $\begin{array}{c}\text { Age group/ } \\
\text { Year }\end{array}$ & $\mathbf{0 - 1 4 \%}$ & $\mathbf{1 5 - 6 4 \%}$ & $\mathbf{6 5 + \%}$ & $\mathbf{0 - 1 4 \%}$ & $\mathbf{1 5 - 6 4 \%}$ & $\mathbf{6 5 + \%}$ \\
\hline 1 & 2 & 3 & 4 & 5 & 6 & 7 \\
\hline $\mathbf{2 0 0 0}$ & 17.8 & 68.0 & 14.2 & 17.6 & 70.1 & 12.3 \\
\hline $\mathbf{2 0 0 1}$ & 17.2 & 68.4 & 14.4 & 16.8 & 70.7 & 12.4 \\
\hline $\mathbf{2 0 0 2}$ & 16.6 & 68.8 & 14.5 & 16.0 & 71.3 & 12.6 \\
\hline $\mathbf{2 0 0 3}$ & 16.2 & 69.2 & 14.7 & 15.3 & 71.6 & 13.1 \\
\hline $\mathbf{2 0 0 4}$ & 15.7 & 69.6 & 14.7 & 14.9 & 71.7 & 13.5 \\
\hline $\mathbf{2 0 0 5}$ & 15.3 & 69.9 & 14.8 & 14.5 & 71.6 & 13.9 \\
\hline $\mathbf{2 0 0 6}$ & 14.9 & 70.2 & 14.9 & 14.2 & 71.7 & 14.1 \\
\hline
\end{tabular}




\begin{tabular}{|c|c|c|c|c|c|c|}
\hline 1 & 2 & 3 & 4 & 5 & 6 & 7 \\
\hline $\mathbf{2 0 0 7}$ & 14.5 & 70.5 & 15.0 & 14.0 & 71.9 & 14.2 \\
\hline $\mathbf{2 0 0 8}$ & 14.3 & 70.8 & 15.0 & 13.9 & 72.2 & 13.8 \\
\hline $\mathbf{2 0 0 9}$ & 14.1 & 70.9 & 15.0 & 14.1 & 72.5 & 13.4 \\
\hline $\mathbf{2 0 1 0}$ & 14.0 & 71.0 & 15.0 & 14.3 & 72.8 & 12.9 \\
\hline $\mathbf{2 0 1 1}$ & 14.1 & 71.0 & 14.9 & 14.5 & 72.9 & 12.6 \\
\hline $\mathbf{2 0 1 2}$ & 14.0 & 70.5 & 15.5 & 14.8 & 72.6 & 12.6 \\
\hline
\end{tabular}

Source: own calculations based on OECD database.

This structural change points out that in the nearest future less and less young people will enter the labour market, while more and more will retire, which means the labour force will shrink. This will certainly limit development prospects of local production systems in Lodzkie Region and in the Novosibirsk Oblast. It seems that the aging of population is a more acute problem in the Lodzkie Region ${ }^{11}$, meaning full utilization of decreasing labour potential will become a crucial factor in order to maintain LPS development and sustain the competitive advantage in the Lodzkie Region. It would require higher efficiency of regional education system and smart development of lifelong learning systems, which allow for better matching of labour force skills with labour market (employers) needs (Kryńska, Arendt 2012). It seems that also in the Novosibirsk Oblast investing in human capital and developing research potential should be key factors of maintaining LPS development.

\section{REGIONAL LABOUR MARKETS ${ }^{12}$}

The pool of human resources available in certain regional and local labour markets is determined mainly by demographic processes described in the previous part of the paper. However, for different reasons, not all people who are in the group of the working-age population are economically active. A relatively low labour force participation rate in Poland in comparison with the EU average, has been highlighted as one of the major challenges for the Polish labour market in the medium-term (Krynska, Arendt 2011). Taking this fact into consideration, the analysis of the labour force participation rate in Lodzkie Region and Novosibirsk Oblast with reference to national level, brings a couple of interesting findings (Table 3).

\footnotetext{
${ }^{11}$ Aging population seems to be the biggest problem in the Lodzkie Region (see OECD 2013a: 67).

${ }^{12}$ Unfortunately, labour market data for the Novosibirsk Oblast, available in the OECD database, cover years up to 2010. This is the reason why analysis in this part of the paper is conducted for the period 2000-2010.
} 
Labour force participation rates (2000-2010)

\begin{tabular}{|l|c|c|c|c|c|c|c|c|c|c|c|c|}
\hline $\begin{array}{l}\text { Region/ } \\
\text { Year }\end{array}$ & $\mathbf{2 0 0 0}$ & $\mathbf{2 0 0 1}$ & $\mathbf{2 0 0 2}$ & $\mathbf{2 0 0 3}$ & $\mathbf{2 0 0 4}$ & $\mathbf{2 0 0 5}$ & $\mathbf{2 0 0 6}$ & $\mathbf{2 0 0 7}$ & $\mathbf{2 0 0 8}$ & $\mathbf{2 0 0 9}$ & $\mathbf{2 0 1 0}$ & $\begin{array}{c}\mathbf{2 0 1 0} \\
\mathbf{- 2 0 0 0}\end{array}$ \\
\hline Poland & 66.63 & 66.55 & 65.37 & 63.85 & 63.42 & 64.09 & 62.41 & 62.47 & 62.81 & 63.62 & 64.87 & $\mathbf{- 1 . 7 6}$ \\
\hline $\begin{array}{l}\text { Lodzkie } \\
\text { Region }\end{array}$ & 79.99 & 79.18 & 75.14 & 73.31 & 72.34 & 74.57 & 71.92 & 75.62 & 78.91 & 76.42 & 76.77 & $\mathbf{- 3 . 2 2}$ \\
\hline Russia & 71.60 & 70.09 & 70.65 & 70.69 & 71.4 & 72.13 & 72.99 & 74.11 & 74.49 & 74.05 & 73.51 & $\mathbf{1 . 9 1}$ \\
\hline $\begin{array}{l}\text { Novo- } \\
\text { sibirsk } \\
\text { Oblast }\end{array}$ & 72.36 & 68.09 & 70.23 & 70.28 & 69.61 & 71.83 & 71.78 & 72.42 & 74.93 & 73.19 & 73.40 & $\mathbf{1 . 0 4}$ \\
\hline
\end{tabular}

Source: OECD database.

Firstly, labour force participation rate in the period 2000-2010 in the Lodzkie Region was significantly higher than Poland's average, while in the Novosibirsk Oblast, with the exception of 2000 and 2008, it was slightly below Russian Federation's average.

Secondly, changes of the labour force participation rate in the Lodzkie Region followed a U-shape path - we witnessed a decrease between 2000 and 2006, and then recovery, but insufficient to reach its initial level (labour force participation rate in 2010 was lower by 3.22 p.p. in comparison with 2000). In the Novosibirsk Oblast sharp decline in the labour force participation rate in 2001 was followed by a steady growth, which stopped in 2009. Nevertheless, labour force participation rate in 2010 was higher by 1.04 p.p. than in 2000 .

Thirdly, in the whole period between 2000-2010, labour force participation rate in Lodzkie Region was higher than in the Novosibirsk Oblast. The biggest difference was reported in 2001 (11.09 p.p. $)^{13}$.

The main conclusions stemming from this analysis are twofold:

- the tendency of the labour force participation rate to increase between 2000 and 2010 is a positive feature of labour market in the Novosibirsk Oblast,

- although labour force participation rate in the Lodzkie Region is perceived as too low, it is still higher than in the Novosibirsk Oblast. It means that working-age population in the Lodzkie Region is more willing to be active on the labour market that it is in case of the inhabitants of the Novosibirsk Oblast.

\footnotetext{
${ }^{13}$ In 2006 the difference was only 0.14 p.p., while in 2008 it amounted to 3.98 p.p.
} 


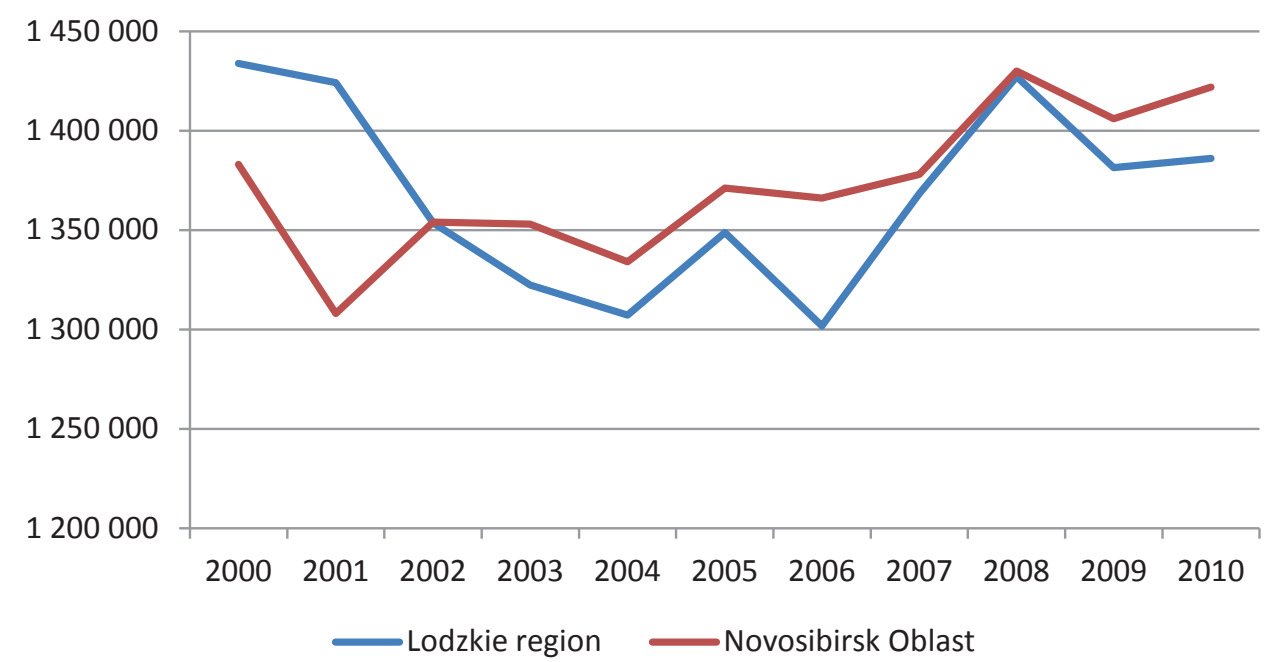

Figure 4. Labour force in Lodzkie Region and the Novosibirsk Oblast (2000-2010)

Source: based on data from OECD database.

Economically active population in the Lodzkie Region fell by 3.3\% between 2000 and 2010, while in the Novosibirsk Oblast it grew by 2.8\%. Labour force in the Novosibirsk Oblast was constantly higher than in Lodzkie Region since 2002 (Figure 4).

The comparison of the employment rate and the number of employed between Lodzkie Region and the Novosibirsk Oblast reveals that these two regional labour markets followed quite different paths in 2000-2010 period.

Employment rate in Lodzkie Region was significantly higher than the Polish average (the difference varied from 7.42 p.p. in 2004 to 15.3 p.p. in 2008), while in the Novosibirsk Oblast it was below the Russian average, but catching up successfully in 2010 (Table 4)! The increase of the employment rate in the Novosibirsk Oblast was exceptional - it grew by 7.28 p.p. - from $59.13 \%$ in 2000 to $66.41 \%$ in 2010 (three times more than the growth for the Russian Federation in that period!).

Table 4

Employment rates (2000-2010)

\begin{tabular}{|c|c|c|c|c|c|c|c|c|c|c|c|c|}
\hline $\begin{array}{l}\text { Region/ } \\
\text { Year }\end{array}$ & $\mathbf{2 0 0 0}$ & $\mathbf{2 0 0 1}$ & $\mathbf{2 0 0 2}$ & $\mathbf{2 0 0 3}$ & $\mathbf{2 0 0 4}$ & $\mathbf{2 0 0 5}$ & $\mathbf{2 0 0 6}$ & $\mathbf{2 0 0 7}$ & $\mathbf{2 0 0 8}$ & $\mathbf{2 0 0 9}$ & $\mathbf{2 0 1 0}$ & $\begin{array}{c}\mathbf{2 0 1 0} \\
\mathbf{- 2 0 0 0}\end{array}$ \\
\hline 1 & 2 & 3 & 4 & 5 & 6 & 7 & 8 & 9 & 10 & 11 & 12 & 13 \\
\hline Poland & 55.76 & 54.33 & 52.37 & 51.48 & 51.32 & 52.71 & 53.71 & 56.47 & 58.34 & 58.42 & 58.63 & $\mathbf{2 . 8 7}$ \\
\hline $\begin{array}{c}\text { Lodzkie } \\
\text { Region }\end{array}$ & 67.07 & 63.68 & 59.97 & 59.42 & 58.74 & 61.60 & 62.26 & 68.60 & 73.64 & 70.63 & 69.66 & $\mathbf{2 . 5 9}$ \\
\hline Russia & 63.63 & 63.85 & 64.22 & 64.62 & 65.19 & 65.79 & 66.3 & 67.23 & 67.46 & 66.20 & 66.01 & $\mathbf{2 . 3 8}$ \\
\hline
\end{tabular}


Table 4 (cont.)

\begin{tabular}{|c|c|c|c|c|c|c|c|c|c|c|c|c|}
\hline 1 & 2 & 3 & 4 & 5 & 6 & 7 & 8 & 9 & 10 & 11 & 12 & 13 \\
\hline $\begin{array}{l}\text { Novo- } \\
\text { sibirsk } \\
\text { Oblast }\end{array}$ & 59.13 & 58.6 & 58.79 & 61.95 & 62.90 & 64.00 & 64.63 & 65.42 & 66.61 & 65.38 & 66.41 & $\mathbf{7 . 2 8}$ \\
\hline
\end{tabular}

Source: OECD database.

At the same time, the increase in the employment rate in the Lodzkie Region was below the Polish average (respectively, 2.59 p.p. and 2.87 p.p.). It is worth noting that while in the Novosibirsk Oblast employment rate was growing almost continuously each year (except for 2001 and 2009), Lodzkie Region saw significant fall in the employment rate between 2000 and 2004, then quite a sharp increase till 2008, followed by the next fall in 2009 and 2010 (Table 4). At the end of the analysed period (2010), the employment rate in the Lodzkie Region was higher by 3.25 p.p. than in the Novosibirsk Oblast.

The number of employed increased in both regions between 2000 and 2010, however, in the Novosibirsk Oblast this growth was truly significant $(13.9 \%$ in comparison with $4.6 \%$ in the Lodzkie Region). Moreover, employment changes were more stable in the Novosibirsk Oblast (which implies higher stability of the economy in this region) - as a result, the employment in the Novosibirsk Oblast for most of the years between 2000-2010 was higher than in the Lodzkie Region (in 2010 it was higher by 28,900 persons) (Figure 5).

The analysis of unemployment shows, that the situation in the regional labour market in the Lodzkie Region was much tougher than in the Novosibirsk Oblast. The number of unemployed in the Novosibirsk Oblast was higher than in the Lodzkie Region only in 2008 and 2009.

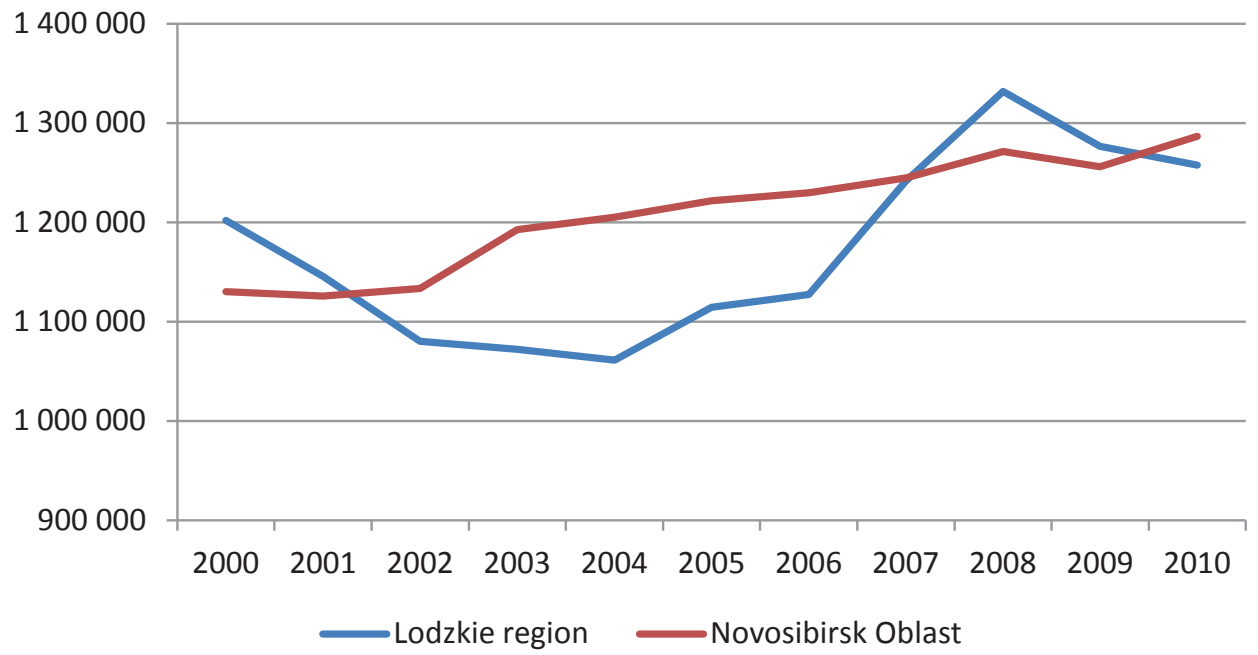

Figure 5. Employment in Lodzkie Region and the Novosibirsk Oblast (2000-2010)

Source: based on data from OECD database. 
In 2004 and 2005 the number of unemployed in the Lodzkie Region was twice as high as in the Novosibirsk Oblast! Reduction of unemployment in Poland, and in the Lodzkie Region, was a remarkable achievement. Unfortunately, after years of decline, unemployment in the Lodzkie Region started to grow in 2008, which was connected with the consequences of the world economic crisis (Figure 6).

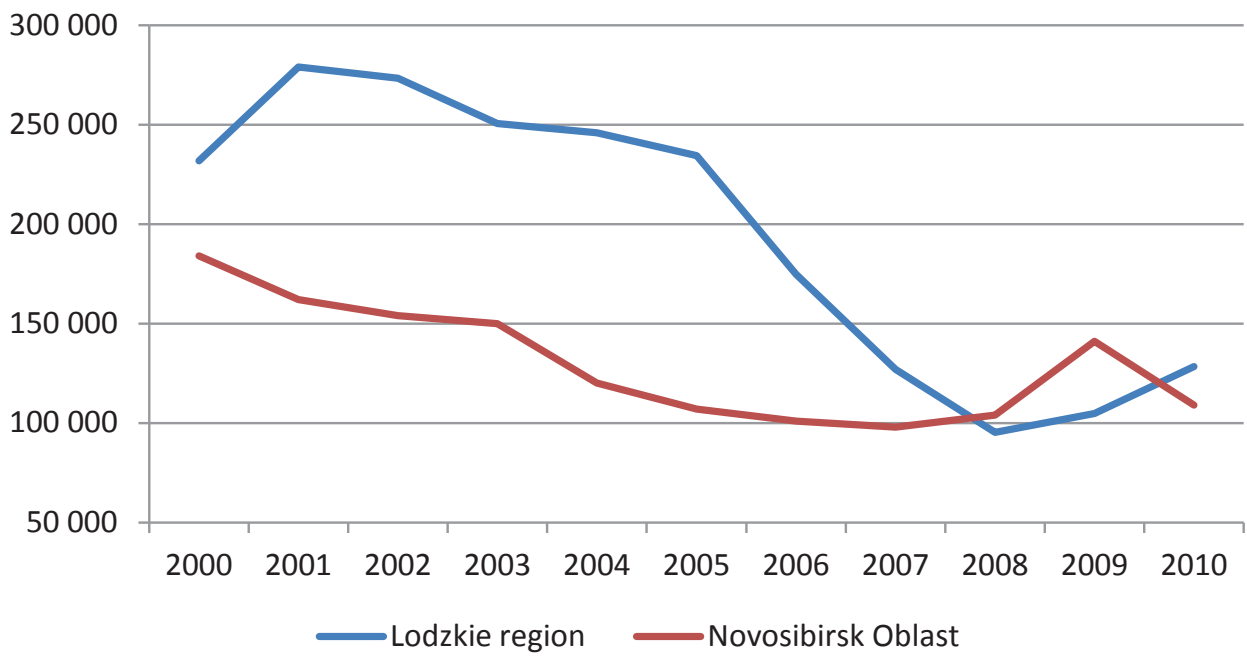

Figure 6. Number of unemployed in Lodzkie Region and the Novosibirsk Oblast (2000-2010)

Source: based on data from OECD database.

The crisis also influenced unemployment in the Novosibirsk Oblast, but in this case the number of unemployed, after a sharp increase in 2009 , returned to its 2008 level.

The analysis of unemployment rate also confirms the existence of huge differences between Lodzkie Region and Novosibirsk Oblast. Within the whole analysed period, unemployment rate in the Lodzkie Region was higher than in the Novosibirsk Oblast. The highest unemployment rate (in years 2000-2012) in the Lodzkie Region reached $20.2 \%$ in 2003 (which means than around $1 / 5$ of the labour force was seeking employment but could not find any); in the Novosibirsk Oblast it was "only" $13.3 \%$ in 2000 . The growing divergence between these two regions in the unemployment rate is clearly noticeable in last years, which may imply, that the Lodzkie Region has been more vulnerable to the world economic crisis $^{14}$ (Table 5).

${ }^{14}$ This vulnerability may be explained by many factors, which might be related to economy-driven or labour market-driven determinants. One of the economy-driven factors is greater openness of the Lodzkie Region to international cooperation and trade (thus, the sharp fall in foreign demand caused by economic crisis had to result in deeper adjustment processes on the labour market). 
Unemployment rates (2000-2012)

\begin{tabular}{|l|c|c|c|c|c|c|c|c|c|c|c|c|c|c|}
\hline $\begin{array}{l}\text { Region/ } \\
\text { Year }\end{array}$ & $\mathbf{2 0 0 0}$ & $\mathbf{2 0 0 1}$ & $\mathbf{2 0 0 2}$ & $\mathbf{2 0 0 3}$ & $\mathbf{2 0 0 4}$ & $\mathbf{2 0 0 5}$ & $\mathbf{2 0 0 6}$ & $\mathbf{2 0 0 7}$ & $\mathbf{2 0 0 8}$ & $\mathbf{2 0 0 9}$ & $\mathbf{2 0 1 0}$ & $\mathbf{2 0 1 1}$ & $\mathbf{2 0 1 2}$ & $\begin{array}{c}\mathbf{2 0 1 2} \\
\mathbf{- 2 0 0 0}\end{array}$ \\
\hline Poland & 16.3 & 18.4 & 19.9 & 19.4 & 19.1 & 17.8 & 13.9 & 9.6 & 7.1 & 8.2 & 9.6 & 9.7 & 10.1 & $\mathbf{- 6 . 2}$ \\
\hline $\begin{array}{l}\text { Lodzkie } \\
\text { Region }\end{array}$ & 16.2 & 19.6 & 20.2 & 18.9 & 18.8 & 17.4 & 13.4 & 9.3 & 6.7 & 7.6 & 9.3 & 9.3 & 11.1 & $\mathbf{- 5 . 1}$ \\
\hline Russia & 10.6 & 9.0 & 7.9 & 8.2 & 7.8 & 7.2 & 7.1 & 6.1 & 6.3 & 8.4 & 7.5 &. &. & $\mathbf{- 3 . 1 ^ { * }}$ \\
\hline $\begin{array}{l}\text { Novo- } \\
\text { sibirsk } \\
\text { Oblast }\end{array}$ & 13.3 & 12.4 & 11.4 & 11.1 & 9.0 & 7.8 & 7.4 & 7.1 & 7.3 & 10.0 & 7.7 & 6.8 & 5.6 & $\mathbf{- 7 . 7}$ \\
\hline
\end{tabular}

* Difference is calculated for year 2010 and 2000.

Source: OECD database.

\section{SUMMARY}

The development of local production systems depends on many interlinked factors - localisation, available infrastructure, the abundance of natural resources, stock of human capital. The paper focuses on two regions: the Lodzkie Region in Poland and the Novosibirsk Oblast in Russian Federation. It discusses development perspectives of these regions in terms of economy, innovativeness and demographics. It also presents a comparative analysis of two regional labour markets. The research brought some interesting findings in terms of future potential and development of local production systems in these regions.

The phenomenon of an aging society is noticeable in both regions, but demographic potential is stronger in the Novosibirsk Oblast. Ageing society may limit LPS development prospects in the Lodzkie Region, which is less likely to happen in the Novosibirsk Oblast. Nevertheless, it is crucial both to invest in human

On the other hand, this higher vulnerability of the Lodzkie Region may be caused by labour market frictions that work differently in analysed regions. The argument is related to theoretical concept of matching labour demand and supply (Beveridge curve framework) and search frictions on the labour market presented by Diamond, Mortensen and Pissarides (known as DMP model) (see Mortensen 2011). The DMP model implies that, because of frictions, labour market does not clear and unemployment and vacancies coexist. Moreover, bringing back unemployment to the equilibrium level after an adverse economic shock takes time, even if new jobs are created, as the hiring process is time-consuming. 
capital and to develop educational and research potential in accordance with labour market needs in order to reduce negative effects of labour force decline.

It would also be desirable to undertake actions aimed at raising the participation of working-age population. Two parallel forms of such actions seem to be needed. The first one is a systemic approach implemented by the central government in the labour market and in demographic policies. The other is to create incentives and programmes (e.g. introduction of age management systems in companies and institutions) at regional level with the cooperation of local as well as regional authorities, businesses and non-governmental organisations. Such actions should exert great impact especially in the Novosibirsk Oblast, where, despite positive growth tendency as for the labour force participation rate, its level is still unsatisfactory. In the medium-term a real challenge in the Novosibirsk Oblast would be to maintain employment growth; for the Lodzkie Region - to return to employment growth path.

Although the unemployment rate during the period of the global economic crisis was lower in the Novosibirsk Oblast, it is difficult to unequivocally conclude that the Novosibirsk's labour market creates better environment for LPS development compared to the Lodzkie Region. Higher resistance to unfavourable changes in international markets represented by the Novosibirsk Oblast may stem from many interlinked factors - i.e. lower openness to international trade, different structure of the labour market, different matching processes between new job openings and job seekers, institutional framework influencing the mechanism of search frictions, etc. It seems that greater openness to international cooperation and open innovation strategy, connected with implementation of knowledge-sharing practices and age management systems are of a key importance for the LPS creation and development.

\section{REFERENCES}

EURIS (2013), Lodzkie Region Policy Brief.

Granberg A.G., Mikheeva N.N., Ershow Yu.S., Kuleshov V.V., Seliverstov V.E., Suslov V.I., Suspitsyn S.A., Minakir P.A. (2011), The Impact of the Global Crisis on the Strategy of Spatial Socio-Economic Development of the Russian Federation, "Regional Research of Russia", vol. 1, no. 1, p. 2-14.

KPMG (2012), Specjalne strefy ekonomiczne w Polsce. Edycja 2012.

Kryńska E., Arendt Ł. (2012), Kapitat ludzki a potrzeby rynku pracy województwa łódzkiego, „Polityka Społeczna", no. 11-12, p. 1-5.

Kryńska E., Arendt Ł. (2011), Rynek pracy i kierunki wzrostu aktywności zawodowej ludności na obszarze zachodnich województw Polski w kontekście prowadzonej polityki regionalnej, research paper commissioned by the Ministry of Regional Development, Warsaw.

Lenchuk E.B., Vlaskin G.A. (2010), A Cluster-Based Strategy for Russia's Innovative Development, "Studies on Russian Economic Development", vol. 21, no. 6, p. 603-611. 
Lodzkie 2020 (2013), Strategia Rozwoju Województwa Eódzkiego 2020, Biuro Planowania Przestrzennego Województwa Łódzkiego, Łódź.

Lombardi M. (2003), The evolution of local production systems: the emergence of the "invisible mind" and the evolutionary pressures towards more visible "minds", "Research Policy", vol. 32 , no. 8 , p. 1443-1462.

LORIS 2030 (2013), Regionalna Strategia Innowacji dla Województwa Łódzkiego - , LORIS 2030”, Deloitte, ŁARR, Łódź.

Mortensen D.L. (2011), Markets with Search Friction and the DMP Model, "American Economic Review", vol. 101, no. 4, p. 1073-1091.

OECD (2013a), Demographic Transition and an Ageing Society: Implications for Local Labour Markets in Poland.

OECD (2013b), tódzkie Region: Demographic Challenges within an Ideal Location, OECD Local Economic and Employment Development (LEED) Working Paper Series.

PAG Uniconsult (2009), Ocena funkcjonowania klastrów województwa łódzkiego - studia przypadków w kontekście realizacji RPO WE. Raport końcowy.

PARP (2011), Innovations Centers in Poland. Directory of innovative business support institutions, Warsaw.

Perret J.K. (2014), Knowledge as a Driver of Regional Growth in the Russian Federation, Springer, Heidelberg-New York-Dordrecht-London.

Petukhova S.P. (2011), Information Technologies as a Basis for the Modernization of Russian Intellectual Resources, "Studies on Russian Economic Development", vol. 22, no. 4, p. 375-383.

PWC (2011), Guide to investment. Part 9. Novosibirsk Region.

Romanova O.A., Grebenkin A.V., Akberdina V.V. (2012), Effect Produced by Innovation Dynamics on the Development of Regional Economic System (Case Study of Sverdlovsk and Novosibirsk Oblasts), "Regional Research of Russia", vol. 2, no. 3, p. 214-224.

Samul J. (2013), Definicje kapitału ludzkiego w ujęciu porównawczym, "Zeszyty Naukowe Uniwersytetu Przyrodniczo-Humanistycznego w Siedlcach, Seria: Administracja i Zarządzanie", vol. 96, no. 23, p. 195-204.

Seliverstov V.E., Melnikova L.V. (2013), Analysis of Strategic Planning in Regions of the Siberian Federal District, "Regional Research of Russia", vol. 3, no. 1, p. 96-102.

Suspitsyn S.A. (2012), Forecasts and Estimates of Spatial Transformations of the Economy on the Basis of a Complex of Hierarchical Calculations of the Multiregional System Development of Russia, "Regional Research of Russia", vol. 2, no. 2, p. 93-101.

Suzigan W., Furtado J., Garcia R. (2007), Designing Policies for Local Production Systems: A Methodology Based on Evidence from Brazil, "Economia, Brasilia" (DF), vol. 8, no. 1, p. 161-186.

The Territories of the Russian Federation (2012), Routledge.

Untura G.A. (2013), Strategic Support of the Russian Regions: Problems of the Assessment of the Status of Innovative Territories, "Regional Research of Russia", vol. 3, no. 2, p. 153-161.

Vavilina N.D. (2013), Social Portrait of Siberian Regions, "Regional Research of Russia", vol. 3, no. 3, p. 291-300. 